\title{
ANALISIS TEKNOLOGI PEMBELAJARAN DALAM PENDIDIKAN SEKOLAH DASAR
}

\author{
Devie Anggraeny ${ }^{1}$, Dina Aulia Nurlaili ${ }^{2}$, Rachil Amalia Mufidah ${ }^{3}$ \\ Universitas Muhammadiyah Tangerang \\ anggraenydevie66@gmail.com,dinaaulia712@gmail.com
}

\begin{abstract}
This study aims to find out about the extent to which technology plays a role in the continuity of learning in SDN Karang Tengah 11. And to find out what are the advantages and disadvantages of learning technology in the SDN. The method used in this research is descriptive qualitative method. In education, learning using technology carried out by the teacher is very helpful in the learning process. Especially for elementary school students whose characteristics are still at an early development stage, therefore teachers need to use technology as a learning medium so that students are more interested in participating in learning. Teachers also need to understand about technology in the current era so that teachers in Indonesia are not out of date. From the results of the study it was found that the teachers at SDN Karang Tengah 11 had used technology in learning, such as displaying pictures, films, and others using a projector.
\end{abstract}

Keywords: Education, Technology

\begin{abstract}
Abstrak: Penelitian ini bertujuan untuk mengetahui tentang sejauh mana teknologi berperan dalam kelangsungan pembelajaran di SDN Karang Tengah 11. Serta mengetahui apa saja kekurangan dan kelebihan teknologi pembelajaran di SDN tersebut. Metode yang digunakan dqalam penelitian ini adalah metode deskriptif kualitatif. Dalam pendidikan, pembelajaran menggunakan teknologi yang dilakukan oleh guru sangat membantu proses pembelajaran. Khususnya untuk siswa siswi sekolah dasar yang karakteristiknya masih pada tahap perkembangan awal, maka dari itu guru perlu menggunakan teknologi sebagai media pembelajaran agar siswa lebih tertarik dalam mengikuti pembelajaran. Guru juga perlu memahami tentang teknologi di era sekarang agar guru-guru di Indonesia tidak ketinggalan zaman. Dari hasil penelitian kedapatan bahwa guru-guru di SDN Karang Tengah 11 sudah menggunakan teknologi dalam pembelajaran, seperti menampilkan gambar, film, dan yang lainnya dengan menggunakan proyektor.
\end{abstract}

Kata Kunci: Pendidikan, Teknologi

\section{PENDAHULUAN}

Pembelajaran menggunakan teknologi berfungsi untuk memberikan kemudahan bagi peserta didik dalam memahami dan mendalami konsep pembelajaran serta dapat menambah semangat belajar, karna materi yang

Fondatia : Jurnal Pendidikan Dasar

Volume 4, Nomor 1, Maret 2020; 150-157

https://ejournal.stitpn.ac.id/index.php/fondatia 
disampaikan menarik perhatian siswa. Pembelajaran yang diberikan kepada siswa harus menimbulkan ketertarikan siswa agar siswa memiliki partisipasi yang antusias dalam kegiatan belajar mengajar. Media yang digunakan berupa gambar dan film yang ditampilkan melalui proyektor.

Pendidikan merupakan gejala semesta (fenomena universal) dan berlangsung sepanjang hayat manusia, dimanapun manusia berada. Dasar Pendidikan adalah landasan berpijak dan arah bagi Pendidikan sebagai wahana pengembangan manusia dan masyarakat. Walaupun Pendidikan itu universal, namun bagi suatu masyarakat, Pendidikan akan diselenggarakan berdasarkan filsafat dana tau pandangan hidup serta berlangsung dalam latar belakang sosial budaya masyarakat tertentu. Secara faktual, kegiatan Pendidikan merupakan kegiatan antar manusia, olehmanusia dan untuk manusia. Itulah mengapa pembicaraan tentang Pendidikan tidak dapat dilepaskan dari pembicaraa tentang manusia. Dalam beberapa sumber pustaka dapat ditemukan berbagai rumusan tentang manusia. Manusia adalah makhluk yang pandai bertanya, bahkan ia mempertanyaakan dirinya sendiri, keberadaannya dan dunia seluruhnya.

Melalui Pendidikan, manusia yang menghuni dunia semesta ini tidak sekedar sebagai potensi demografikal tetapi secara makin sadar menunaikan tugas dan panggilan eksistensinya sebagai potensi kultural. Dalam posisi sadar eksistensinya sebagai kekuatan kultural itu, manusia pada umumnya dan pendidik (guru) khususnya, hendaknya selalu mengembangkan pemahaman terus menerus mengenai Pendidikan didalamnya.

Teknologi adalah keseluruhan sarana untuk menyediakan barang-barang yang diperlukan bagi kelangsungan dan kenyamanan hidup manusia. Penggunaan teknologi oleh manusia diawali dengan pengubahan sumber daya alam menjadi alatalat sederhana. Penemuan prasejarah tentang kemampuan mengendalikan api telah menaikkan ketersediaan sumber-sumber pangan, sedangkan penciptaan roda telah membantu manusia dalam bepergian dan mengendalikan lingkungan mereka. Perkembangan teknologi terbaru, termasuk di antaranya mesin cetak, telepon, dan Internet, telah memperkecil hambatan fisik terhadap komunikasi dan memungkinkan manusia untuk berinteraksi secara bebas dalam skala global. Tetapi, tidak semua teknologi digunakan untuk tujuan damai. Pengembangan senjata penghancur yang 
semakin hebat telah berlangsung sepanjang sejarah dari pentungan sampai senjata nuklir.

Teknologi telah mempengaruhi masyarakat dan sekelilingnya dalam banyak cara. Di banyak kelompok masyarakat, teknologi telah membantu memperbaiki ekonomi (termasuk ekonomi global masa kini) dan telah memungkinkan bertambahnya kaum senggang. Banyak proses teknologi menghasilkan produk sampingan yang tidak dikehendaki yang disebut pencemar dan menguras sumber daya alam, merugikan, dan merusak Bumi dan lingkungannya. Berbagai macam penerapan teknologi telah memengaruhi nilai suatu masyarakat dan teknologi baru seringkali mencuatkan pertanyaan-pertanyaan etika baru. Sebagai contoh: meluasnya gagasan tentang efisiensi dalam konteks produktivitas manusia, suatu istilah yang pada awalnynya hanya menyangkut permesinan. Contoh lainnya adalah tantangan norma-norma tradisional.

Bahwa keadaan ini membahayakan lingkungan dan mengucilkan manusia. Penyokong paham-paham seperti transhumanisme dan tekno-progresivisme memandang proses teknologi yang berkelanjutan sebagai hal yang menguntungkan bagi masyarakat dan kondisi manusia. Tentu saja, paling sedikit hingga saat ini diyakini bahwa pengembangan teknologi hanya terbatas bagi umat manusia, tetapi kajian-kajian ilmiah terbaru mengisyaratkan bahwa primata lainnya dan komunitas lumba-lumba tertentu telah mengembangkan alat-alat sederhana dan belajar untuk mewariskan pengetahuan mereka kepada keturunan mereka.

Meskipun dari tahun ke tahun definisi teknologi pendidikan selalu berkembang, secara garis besar dapat disimpulkan bahwa teknologi pendidikan adalah sebuah bidang studi, teori, sarana, bidang disiplin ilmu, dan praktik etis untuk memfasilitasi dan mempermudah proses pendidikan dan juga sebagai sebuah proses integral dalam menganalisis permasalahan, menemukan solusi, melakukan evaluasi, serta memperoleh pemecahan masalah yang berkaitan dengan semua aspek belajar manusia dengan menggunakan berbagai sumber belajar dan peralatan yang mendukung aspek pembelajaran dan pendidikan. 
Seiring dengan berkembangnya jaman ke era yang lebih modern, teknologi pendidikan juga mengalami perkembangan. Baik di Indonesia maupun dunia. Baik dari segi konsep, definisi, hingga implementasi. Namun satu hal yang pasti yaitu teknologi pendidikan ada untuk menyelesaikan masalah pendidikan yang ada untuk meningkatkan kualitas pendidikan, khususnya di Indonesia.

Walaupun mempunyai nama teknologi pendidikan dan identik dengan media elektronik namun pada kenyataannya teknologi pendidikan tak selalu berhubungan dengan hal tersebut. Seperti contohnya pada awal perkembangan teknologi pendidikan di Indonesia yang lebih mengacu kepada bagaimana sistem pembelajaran diterapkan. Tak selalu membahas media pembelajaran, namun juga membahas mengenai sistem pembelajaran. Selain itu teknologi pendidikan mengedepankan bagaimana pembelajaran tersebut dapat berlangsung lebih efektif.

Ruang lingkup teknologi pendidikan sangatlah luas. Salah satunya teknologi adalah pendidikan sebagai bidang garapan yang meliputi kawasan desain, pengembangan, pemanfaatan, pengelolaan, dan penilaian. Selain itu, peran teknologi pendidikan beraneka ragam. Mulai dari peran yang secara umum sebagai fasilitator untuk meningkatkan kualitas pendidikan dengan menjadikan pembelajaran dalam pendidikan itu menjadi lebih efektif dan efisien. Kemudian perannya dalam masyarakat umum dalam rangka meningkatkan kualitas kemampuannya untuk menambah wawasan dan kecakapan yang pada akhirnya menuju kepada kesejahteraan hidup.

Penggunaan internet dalam proses pembelajaran menjadikan proses pembelajaran berbeda dengan pembelajaran yang dilakukan pendidik sebelum mengenal TIK sehingga akan menarik perhatian peserta didik dalam proses pembelajaran. Pemanfaatan TIK dalam pembelajaran telah mengubah proses pembelajaran "dari ruang kelas ke mana saja, dari waktu siklus ke waktu nyata, dari kertas ke online, dan dari fasilitas fisik ke jaringan kerja" (Abdullah, 2009). Pembelajaran dapat berlangsung di ruang sekolah atau di rumah atau dimana saja bergantung pada kemauan peserta didik. Pemanfaatan TIK ini menyebabkan proses pembelajaran dapat terlaksana tanpa ada pembatasan waktu sepanjang peserta didik 
mau melakukannya. Hal itu akan mendorong peserta didik untuk meningkatkan kompetensinya sesuai dengan kemampuan dan keinginan belajarnya.

Pemanfaatan TIK dalam proses pembelajaran dilakukan dalam berbagai bentuk antara lain penyediaan bahan ajar secara online (bahan ajar tersimpan dalam bentuk buku atau artikel di internet), program computer assisted learning, bahan alat peraga atau simulasi, pembelajaran Moodle dan Facebook (Darmawan dan Siti, 2014), dan pembelajaran jarak jauh (sekolah terbuka). Penyediaan bahan ajar secara online memudahkan pendidik atau peserta didik untuk menemukan bahan ajar sehingga proses pembelajaran tidak terkendala oleh materi bahan ajar yang tidak tersedia.

Ketersediaan bahan ajar secara tepat waktu akan memperlancar dan membantu pendidik atau peserta didik untuk memahami materi pembelajaran secara komprehensif sehingga pembelajaran terhindar kesalahan konsepsi (misconcept). Pembelajaran dengan penggunaan alat peraga atau simulasi melalui TIK akan memudahkan materi pelajaran dipahami oleh peserta didik serta akan berdampak pada minat atau perhatian peserta didik pada pelajaran tersebut. Adanya alat peraga dengan penerapan TIK akan membuat pembelajaran lebih menyenangkan dan menarik perhatian peserta didik. Dengan demikian, komputer berfungsi untuk membantu peserta didik untuk memelajari materi pelajaran secara terprogram sesuai dengan kompetensi yang ditetapkan dalam kurikulum serta perkembangan kemampuannya.

Penerapan TIK untuk pendidikan jarak jauh telah berkembang lama terutama di negara maju. Dalam penggunaan TIK jarak jauh dilakukan secara interaktif antara pendidik dengan peserta didik. Pendidik menjelaskan materi pelajaran melalui internet kepada peserta didik di pedalaman dan bila ada yang kurang jelas, peserta didik dapat meminta penjelasan ulang secara online. Melalui penggunaan TIK yang ada, peserta didik dapat mengajukan pertanyaan kepada pendidik dan dijawab secara langsung. Pada akhir pembelajaran pendidik memberikan tugas sebagai penilaian pembelajaran dan setelah tugas dikerjakan maka dilakukan diskusi secara langsung (online). 
Pemanfaatan TIK dalam pembelajaran diyakini dapat meningkatkan kualitas pembelajaran dan peserta didik lebih mudah untuk menerima materi pembelajaran. Untuk mengukur pencapaian peserta didik dalam proses pembelajaran dilakukan penilaian. Penilaian dalam proses pembelajaran, menurut Bennet dan Gitomer (2009) dibedakan sebagai alat untuk mendeteksi kesulitan belajar (assessment as learning), penilaian proses pembelajaran (assessment for learning), dan penilaian untuk mengukur pencapaian hasil belajar (assessment of learning).

\section{METODE PENELITIAN}

Dalam penelitian ini kami menggunakan metode wawancara. Di bawah ini adalah pertanyaan yang telah kami buat untuk mewawancarai narasumber sesuai dengan materi yang akan kami teliti:

1. Sejauh mana perkembangan teknologi membantu guru dalam proses pengajaran dikelas?

2. Apa tanggapan gurur-guru disekolah ini tentang perkembangan teknologi yang begitu pesat terutama dalam meningkatkan proses pembelajaran peserta didik?

3. Apa problem mendasar yang masih dihadapi guru-guru disekolah ini yang berkaitan dengan penerapan atau pengaplikasian teknologi pendidikan dalam $\mathrm{p}$ [roses pembelajaran?

4. Bagaimana ibu menggambarkan kemajuan teknologi pendidikan terhadap peningkatan kualitas guru maupun peserta didik?

5. Bagaimana cara mengajarkan IT ke anak sd?

6. Menurut ibu apa hubungan antara media teknologi dengan pembelajaran?

Berikut ini adalah jawaban dari hasil wawancara kami dengan salah satu guru di SD Negeri Karang Tengah 11

1. Teknologi didalam SD Negeri Karang Tenagh 11 sudah canggih, seperti adanya proyektor, dalam pembelajaran menggunkan proyektor pembelajaran lebih di sukai dan di minati siswa karena menarik, tetapi tidak semua mata pelajaran yang melakukan pembelajaran menggunakan proyektor, hanya pada 
saat moment-moment tertentu saja seperti pada saat menonton bersama, menampilkan gambar.

2. Memang teknologi jaman sekarang sudah canggih dan memadai, kendalanya hanya ketika siswa diminta mencari sesuatu di internet tetapi orang tua siswa tidak memiliki gadget tetapi menurut salah satu guru di SD Negeri Karang Tengah 11 bisa juga dengan pergi ke warnet dan mencari di internet, lalu kendalanya juga ada karena kekhawatiran guru-guru yang takut siswanya mencari yang tidak-tidak diinternet.

3. Terkadang masih ada guru-guru yang masih belum mengerti bagaimana cara menggunakan teknologi yang ada, jika seperti itu kadang guru-guru meminta tolong kepada operator sekolah ataupun TU

4. Teknologi zaman sekarang sangat bagus untuk guru dan siswa karena sangat bermanfaat, apalagi saat ini guru sedang di galakkan mengenai e-rapot, guru diharuskan menginput nilai siswa secara online dan mau tidak mau guru harus bisa menggunakan e-rapot tetapi terkadang ada kendalanya seperti sinyalnya yang kurang, dan loadingnya yang lama

5. Dengan cara, semisal ada materi yang tidak ada dibuku maka guru meminta siswa untuk mencarinya di rumah lewat internet dengan bantuan orang tua.

6. Pemanfaatan media komunikasi telah berkembang cukup lama di Negaranegara maju, yang dimaksudkan dengan media pemanfaatan media ini ialah media elektronika dan fotografi. Jadi radio, film, TV, bahkan computer untuk pembelajaran terprogram. Di Negara-negara maju lainnya misalnya jepang, orang menggunkan TV atau siaran TV terbatas. Media komunikasi yang pada mulanya adalah alat hiburan dan alat penyampaian pesan-pesan penerangan, bukan di desain untuk tujuan pembelajaran. Kemudan para ahli melihat potensi yang ada pada media ini untuk dimanfaatkan bagi pendidikan, terlihat potensi yang besar dan luas dari media ini untuk digunakan menjadi alat penyampaian pesan-pesan pembelajaran, maka jadilah ia media pembelajaran. Media ini dapat mecapai sasaran anak tidak hanya didalam kelas pada waktu yang sama, bahkan tempat yang jah di luar kelas. Ia dapat mencapai sasaran yang terpencil di gunung-gunung atau di pulau-pulau kecil yang jauh dari sekolah atau pusat belajar. Ia dapat digunkan pula untuk pendidikan 
masyarakat baik untuk meningkatkan kemampuannya maupun untuk pendidikan/pemberantasan buta huruf.

\section{HASIL DAN PEMBAHASAN}

Dari hasil penelitian kami dapat membuktikan bahwa pembelajaran menggunakan teknologi pada zaman sekarang sudah sangat canggih, di SD Negeri Karang tengah 11 misalnya, mereka sudah menggunakan teknologi yang canggih sebagai media pembelajaran mereka, teknologi yang mereka pakai berupa menampilkan gambar ataupun film melalui proyektor. Dengan menggunakan proyektor pembelajaran yang di lakukan akan menarik perhatian para siswa-siswinya karena karakteristik atau sikap anak sekolah dasar masih dalam tahap tahap perkembangan awal yang rasa ingin tahunya sangat tinggi. Tidak hanya mengenai proyektor sebagai media pembelajaran yang menarik saja, guru di SD Negeri Karang Tengah 11 juga merasakan teknologi yang berkembang dengan pesat pada zaman sekarang ini yaitu dengan adanya e-rapot guru di haruskan menginput nilai-nilai siswa secara online. Dengan berembangnya teknologi dimasa sekarang pembelajaran juga tidak hrus selalu di lakukan di dalam kelas saja, tetapi bisa di lakukan dimana saja dan kapan saja.

\section{KESIMPULAN}

Dalam perkembangan teknologi pembelajaran seorang guru harus menciptakan atau memperkenalkan beberapa media pembelajaran yang menggunakan teknologi, yang menarik perhatian dan minat belajar siswa dan siswinya sehingga siwa dan siswi semangat dan fokus terhadap materi yang disampaikan.

\section{DAFTAR PUSTAKA}

Dwi Siswoyo, dkk. 2013. Ilmu Pendidikan. Yogyakarta : UNY Press Haryanto. 2015. Teknologi Pendidikan. Yogyakarta : UNY Press https://www.padamu.net/penggunaan-teknologi-dalam-pembelajaran 